\title{
Enterococcus avium nom. rev., comb. nov.; E. casseliflavus nom. rev., comb. nov.; E. durans nom. rev., comb. nov.; E. gallinarum comb. nov.; and $E$. malodoratus sp. nov.
}

\author{
M. D. COLLINS, ${ }^{1}$ D. JONES, ${ }^{2 *}$ J. A. E. FARROW, ${ }^{1}$ R. KILPPER-BÄLZ, ${ }^{3}$ AND K. H. SCHLEIFER ${ }^{3}$ \\ Department of Microbiology, National Institute for Research in Dairying, Shinfield, Reading RG2 9AT, United Kingdom ${ }^{1}$; \\ Department of Microbiology, University of Leicester, Leicester LE1 7RH, United Kingdom ${ }^{2}$; and Lehrstuhl für \\ Mikrobiologie, Technische Universitat München, 8000 München 2, Federal Republic of Germany ${ }^{3}$
}

Biochemical, chemical, and genetic data indicate that strains labeled Streptococcus avium (Nowlan and Deibel), "Streptococcus casseliflavus" (Vaughn, Riggsby and Mundt), "Streptococcus durans" (Sherman and Wing), "Streptococcus faecalis subsp. malodoratus" (Pette), and Streptococcus gallinarum (Bridge and Sneath) are closely related to members of the genus Enterococcus Schleifer and Kilpper-Bälz. We propose that these taxa be classified as members of the genus Enterococcus, as Enterococcus avium nom. rev., comb. nov., Enterococcus casseliflavus nom. rev., comb. nov., Enterococcus durans nom. rev., comb. nov., Enterococcus malodoratus sp. nov., and Enterococcus gallinarum comb. nov., respectively.

The inclusion of Streptococcus faecalis and Streptococcus faecium in the genus Streptococcus has been controversial for some time (12). Kalina (14) proposed that these species be transferred to the genus "Enterococcus" of Thiercelin and Jouhaud (25). However, this proposal was not generally accepted, and the genus Enterococcus was not recognized in Bergey's Manual of Determinative Bacteriology, 8th ed. (5). Recent nucleic acid studies $(10,15,21)$ have indicated that $S$. faecalis and $S$. faecium are quite distinct from the majority of the species in the genus Streptococcus. Consideration of these data led Schleifer and Kilpper-Bälz (21) to repropose the transfer of $S$. faecalis and $S$. faecium to the genus Enterococcus (ex Thiercelin and Jouhaud) Schleifer and Kilpper-Bälz.

In addition to $S$. faecalis and $S$. faecium, a number of other streptococci conform to the characteristics of the enterococcus division of Sherman (22). These include "Streptococcus avium" (18), "Streptococcus casseliflavus", (26), "Streptococcus durans"' (23), "S. faecalis subsp. malodoratus" (19), and "S. faecium subsp. mobilis" (16), none of which were included on the Approved Lists of Bacterial Names (24), as well as the recently described species Streptococcus gallinarum (3). Recent deoxyribonucleic acid (DNA)-DNA and DNA-ribosomal ribonucleic acid studies in our laboratories $(10,15,21)$ have shown that these taxa are closely related to Enterococcus faecalis and Enterococcus faecium but only distantly related to other streptococci. The same studies also have indicated that with the exception of " $S$. faecium subsp. mobilis" the taxa listed above are sufficiently distinct (less than 30\% DNA-DNA homology under stringent hybridization conditions) from each other to be considered separate species (10). Strains designated " $S$. faecium subsp. mobilis" have been shown to be members of the species " $S$. casseliflavus" (76 to 97\% DNA-DNA homology under optimum conditions) (10). On the basis of biochemical, chemical, and genetic data $(3,6,10,13,15,20,21$, 26 , we believe that " $S$. avium," " $S$. casseliflavus," " $S$. durans," "S. faecalis subsp. malodoratus," and S. gallinarum should be transferred to the genus Enterococcus as distinct species.

The purpose of this paper is to propose the classification

\footnotetext{
* Corresponding author.
}

of these taxa as Enterococcus avium nom. rev., comb. nov., Enterococcus casseliflavus nom. rev., comb. nov., Enterococcus durans nom. rev., comb. nov., Enterococcus malodoratus sp. nov., and Enterococcus gallinarum comb. nov., respectively. The physiological, biochemical, chemical, and genetic characteristics of the type strains and representative strains of all of these species have been published previously by us and other workers $(1-4,6,10,11$, $15-21,23,26$ ).

The strains of all of the species conform in the main to the characteristics of the genus Enterococcus (ex Thiercelin and Jouhaud) Schleifer and Kilpper-Bälz. They are all grampositive, facultatively anaerobic, catalase-negative cocci which occur mostly in pairs or short chains; grow at $10^{\circ} \mathrm{C}$ and, unless otherwise stated below, at $45^{\circ} \mathrm{C}$; survive heating at $60^{\circ} \mathrm{C}$ for $30 \mathrm{~min}$; grow in $6.5 \%$ (wt/vol) $\mathrm{NaCl}$, at $\mathrm{pH} 9.6$, and in $40 \%$ (vol/vol) bile; and produce L-lactic acid as the major end product of glucose fermentation.

Enterococcus avium. The following description of Enterococcus avium (ex Nowlan and Deibel 1967) nom. rev., comb. nov. (av.i'um. L.n. avis bird; L.gen. pl. avium of birds) is based on previous descriptions $(6,9,10,13,18,20,21)$. Ovoid cells elongated in the direction of the chain, mostly in pairs or short chains. Nonmotile. Surface colonies on blood agar or nutrient agar are circular, smooth, and entire. Nonpigmented. Most strains produce an alpha-reaction on blood agar. No requirement for riboflavin or pyridoxal in casein hydrolysate medium. Folinic acid (or folic acid plus thymine) is required for growth. Amino acid requirements not known. Arginine and starch are not hydrolyzed. $\mathrm{H}_{2} \mathrm{~S}$ produced. Acetylmethylcarbinol not produced. Nitrate is not reduced. Does not grow in the presence of $0.04 \%$ tellurite or in $0.1 \%$ methylene blue milk. Other biochemical characteristics are given in Table 1 . Reacts with Lancefield group D antisera and also usually, but not always, with Lancefield group Q antisera.

Group A peptidoglycan based upon lysine (type, Lys-DAsp). Respiratory quinones absent. The major non-hydroxylated long-chain fatty acids are tetradecanoic $\left(\mathrm{C}_{14: 0}\right)$ and hexadecanoic $\left(\mathrm{C}_{16: 0}\right)$ acids; octadecenoic $\left(\mathrm{C}_{18: 1}\right)$ and cis11,12-methylenoctadecanoic $\left(\Delta \mathrm{C}_{19: 0}\right)$ acids are present in only small amounts (less than $5 \%$ ). Isolated from human, animal, and chicken feces. The guanine-plus-cytosine content of the DNA ranges from 39 to $40 \mathrm{~mol} \%$, as determined 
TABLE 1. Differential biochemical characteristics of E. avium, E. casseliflavus, E. durans, E. faecium, E. faecalis, E. malodoratus, and E. gallinarum ${ }^{a}$

\begin{tabular}{|c|c|c|c|c|c|c|c|}
\hline Characteristic & E. avium & E. durans & E. faecalis & E. faecium & E. malodoratus & E. casseliflavus & $\overline{E . \text { gallinarum }}$ \\
\hline \multicolumn{8}{|l|}{ Acid produced from: $:^{b}$} \\
\hline Adonitol & $+^{c}$ & - & - & - & + & - & - \\
\hline Amidon & - & - & $-(w+)$ & - & - & $-(w+)$ & + \\
\hline L-Arabinose & + & - & - & + & - & + & + \\
\hline D-Arabitol & + & - & - & - & + & - & - \\
\hline L-Arabitol & + & - & - & - & + & - & - \\
\hline Dulcitol & + & - & - & - & + & - & - \\
\hline Glycerol & + & - & t & + & $v$ & - & + \\
\hline Glycogen & - & - & - & - & - & - & $-(+)$ \\
\hline Gluconate & $+(-)$ & - & $+(-)$ & $\mathrm{v}$ & + & + & + \\
\hline Inulin & - & - & - & - & - & + & + \\
\hline 2-Keto-gluconate & + & - & $\mathbf{v}$ & - & + & - & - \\
\hline 5-Keto-gluconate & $\mathrm{v}$ & - & - & - & - & - & - \\
\hline D-Lyxose & + & - & - & - & - & - & - \\
\hline Mannitol & + & $-(+)$ & + & $+(-)$ & + & + & + \\
\hline Melezitose & + & - & $+(-)$ & - & - & - & - \\
\hline Melibiose & - & - & - & $\mathbf{v}$ & + & + & + \\
\hline$\alpha$-Methyl-D-mannoside & $+(-)$ & - & - & $-(+)$ & + & $+(-)$ & - \\
\hline$\alpha$-Methyl-D-glucoside & + & - & - & - & - & + & + \\
\hline D-Raffinose & - & - & - & - & + & - & + \\
\hline Rhamnose & + & - & $\mathrm{v}$ & - & + & $+(-)$ & - \\
\hline Sorbitol & + & - & $+(-)$ & - & + & - & + \\
\hline L-Sorbose & + & - & - & - & + & - & - \\
\hline Sucrose & + & - & + & $\mathbf{v}$ & + & + & + \\
\hline D-Tagatose & + & - & + & - & + & - & + \\
\hline Trehalose & + & $+(-)$ & + & + & + & + & + \\
\hline D-Turanose & + & - & - & - & $\mathbf{v}$ & $\mathrm{v}$ & + \\
\hline Xylitol & + & - & - & - & + & - & - \\
\hline D-Xylose & - & - & - & - & $\mathrm{v}$ & + & + \\
\hline L-Xylose & - & - & - & - & $\mathrm{v}$ & - & - \\
\hline \multicolumn{8}{|l|}{ Hydrolysis of: ${ }^{d}$} \\
\hline Esculin & + & + & $+(-)$ & + & + & + & + \\
\hline Hippurate & $\mathrm{v}$ & $\mathrm{v}$ & $+(-)$ & + & $\mathrm{v}$ & - & + \\
\hline \multicolumn{8}{|l|}{ Production of: ${ }^{d}$} \\
\hline Arginine dehydrolase & - & + & + & + & - & $+(-)$ & + \\
\hline$\alpha$-Galactosidase & - & - & - & - & + & + & + \\
\hline$\beta$-Galactosidase & $\mathrm{v}$ & $\mathrm{v}$ & - & + & + & + & + \\
\hline$\beta$-Glucuronidase & - & - & - & - & - & - & + \\
\hline
\end{tabular}

${ }^{a}$ The following strains were tested: E. avium NCDO 2366, NCDO 2367, NCDO 2368, NCDO 2369 ${ }^{\mathrm{T}}$, and NCDO 2370; $E$. durans NCDO 498, NCDO 593, and NCDO 596 ${ }^{\mathrm{T}} ; E$. faecalis NCDO 581, NCDO 584, NCDO 586, NCDO 588, NCDO 610, and NCDO 611; $E$. faecium NCDO 502, NCDO 503, NCDO 594, NCDO 942, and NCDO 944; E. malodoratus NCDO 846 ${ }^{\mathrm{T}}$ and NCDO 847; E. casseliflavus NCDO $2372^{\mathrm{T}}$, NCDO 2376, NCDO 2378, NCDO 2380, NCDO 2154, and NCDO 2310; and E. gallinarum NCDO 2311, NCDO 2313 ${ }^{\mathrm{T}}$, NCDO 2314 , and NCDO 2315. All strains produced acid from $N$-acetylglucosamine, amygdalin, arbutin, cellobiose, $\mathrm{D}$-fructose, galactose, $\beta$-gentiobiose, $\mathrm{D}$ glucose, lactose, maltose, D-mannose, ribose, and salicin. All strains failed to produce acid from D-arabinose, erythritol, D-fucose, L-fucose, inositol, and $\alpha$-methyl-xyloside.

${ }^{b}$ As determined with the API $50 \mathrm{CH}$ system, using bromocresol purple $(0.002 \%$, wt/vol) as the indicator in $1 \%$ (wt/vol) peptone water.

$c+$, Positive; - , negative; $v$, variable; $+(-)$, most strains positive but occasional strains negative; $-(+)$, most strains negative but occasional strains positive; $-(w+)$, most strains negative but occasional strains weakly positive.

${ }^{d}$ Hippurate, esculin, and enzymatic tests were performed with the API 20 S system according to the instructions of the manufacturer.

by melting temperature. The strains form a distinct homology group, as determined by DNA-DNA hybridization (10). The type strain is NCDO 2369 (= Guthof E6844 = ATCC 14025). This strain was isolated from human feces (11).

Description of the type strain. In most respects the description of the type strain resembles the description of the species. Positive reactions are obtained with Lancefield group $Q$ and group D antisera. Acid is produced from gluconate and from $\alpha$-methyl-D-mannoside. Strain NCDO $2369^{\mathrm{T}}$ ( $\mathrm{T}=$ type strain) produces $\beta$-galactosidase and hydrolyzes hippurate (Table 1).

$E$. avium strains form a distinct species on the basis of genomic $(10)$ and biochemical criteria $(10,18)$ (Table 1). $E$. avium and $E$. malodoratus are the only species of the genus Enterococcus that are known to produce $\mathrm{H}_{2} \mathrm{~S}$ (detected by lead acetate paper inserted into slopes of cultures on blood agar base no. 2 [Oxoid] medium supplemented with $0.05 \%$ [wt/vol] cysteine hydrochloride). However, in contrast to $E$. malodoratus, E. avium strains grow well at $45^{\circ} \mathrm{C}$ and survive heating at $60^{\circ} \mathrm{C}$ for $30 \mathrm{~min}$. In addition, they may be distinguished by their fermentation patterns and by the production of $\alpha$-galactosidase ( $E$. malodoratus produces this compound but $E$. avium does not). $E$. malodoratus never reacts with Lancefield group $Q$ antisera.

Enterococcus casseliflavus. The following description of Enterococcus casseliflavus (ex Vaughn, Riggsby and Mundt 1979) nom. rev., comb. nov. (cass.el.i.fla'vus. M.L. n. casseli of Cassel [Cassel yellow]; L.adj. flavus yellow; casseliflavus yellow colored) is based on previous descriptions $(1,6,10,16,17,21,26)$. Coccoid cells usually in pairs 
or short chains. Motile. Surface colonies on blood agar or nutrient agar are circular, smooth, and entire. Yellow pigment produced. Acetylmethylcarbinol produced. Gray, punctate colonies on agar supplemented with $0.04 \%$ potassium tellurite. $\mathrm{H}_{2} \mathrm{~S}$ not produced. No decarboxylation of tyrosine. Other biochemical properties are given in Table 1. Reacts with Lancefield group D antisera.

Group A peptidoglycan based upon lysine (type, Lys-DAsp). Menaquinones present, with MK-7 and MK-8 as the major isoprenologues (6). The major non-hydroxylated longchain fatty acids are hexadecanoic $\left(\mathrm{C}_{16: 0}\right)$ and octadecenoic $\left(\mathrm{C}_{18: 1}\right)$ acids; cis-11,12-methylenoctadecanoic acid $\left(\Delta \mathrm{C}_{19: 0}\right)$ either is absent or is present in only trace amounts.

Isolated from plants, silage, and soil. The guanine-pluscytosine content of the DNA ranges from 40.5 to $44.9 \mathrm{~mol} \%$, as determined by melting temperature. The strains form a distinct homology group, as determined by DNA-DNA hybridization (10). The type strain is ATCC 25788 (= NCDO $2372=$ MUTK 20). This strain was isolated from plant material (26)

Description of the type strain. In most respects the description of the type strain corresponds with the description of the species. Acid is not produced from amidon. Acid is produced from $\alpha$-methyl-D-mannoside, rhamnose, and D-turanose (Table 1).

In many phenotypic characters $E$. casseliflavus resembles $E$. faecium, but strains of $E$. casseliflavus may be distinguished from E. faecium by some biochemical tests (Table 1 ), by the production of a bright yellow pigment, and by the possession of respiratory quinones (6).

Enterococcus durans. The following description of Enterococcus durans (ex Sherman and Wing 1937) nom. rev., comb. nov. (du'rans. L.part.adj. durans hardening, resisting) is based on previous descriptions $(6-8,10,13,15,20$, 23). Ovoid cells elongated in the direction of the chain, chiefly in pairs or short chains. Surface colonies on blood agar or nutrient agar are circular, smooth, and entire. Nonpigmented. Some strains produce an alpha-reaction on blood agar; a few strains are beta-hemolytic. Nonmotile. Nutritionally exacting; amino acids and B vitamins are required for growth in synthetic media. Grows on $0.1 \%$ methylene blue milk. No growth in media containing $0.04 \%$ tellurite and $0.01 \%$ tetrazolium. $\mathrm{H}_{2} \mathrm{~S}$ is not produced. Other biochemical characteristics are given in Table 1 . Reacts with Lancefield group D antisera.

Group A peptidoglycan based upon lysine (type, Lys-DAsp). Respiratory quinones absent. The major non-hydroxylated long-chain fatty acids are hexadecanoic $\left(\mathrm{C}_{16: 0}\right)$ and octadecenoic $\left(\mathrm{C}_{18: 1}\right)$ acids; substantial amounts of cis-11,12methylenoctadecanoic $\left(\Delta \mathrm{C}_{19: 0}\right)$ acid are also present (approximately $10 \%$ ).

Isolated from milk and dairy products. The guanine-pluscytosine content of the DNA ranges from 38 to $40 \mathrm{~mol} \%$, as determined by melting temperature. There is approximately $40 \%$ homology with the DNA of the type strain of $E$. faecium under optimum hybridization conditions; this value decreases to approximately $20 \%$ under stringent conditions (10). The type strain is NCDO 596 (= ATCC $19432=98 D)$. This strain was isolated from dried milk (23).

Description of the type strain. The type strain differs from most other members of the species by exhibiting betahemolysis on horse blood (5\%, vol/vol) agar plates. It does not produce acid from mannitol or trehalose, nor does it hydrolyze hippurate. It does produce $\beta$-galactosidase (Table 1).

On the basis of phenotypic characters, it is not easy to distinguish strains of $E$. durans from $E$. faecium. Indeed, it has been suggested that on the basis of phenotypic criteria the two taxa should be combined $(9,12)$. However, the data of Jones et al. (13) show that strains labeled $S$. faecium and "S. durans" occupy a large area of phenetic space, with " $S$. durans" strains showing a closer similarity to each other than to $S$. faecium strains. Strains of E. faecium are more saccharolytic than strains of $E$. durans (Table 1). In addition, strains of $E$. faecium grow in nutrient broth no. 2 (Oxoid) supplemented with $0.1 \%$ glucose incubated at $50^{\circ} \mathrm{C} . E$. durans strains do not grow at $50^{\circ} \mathrm{C}$. These differences, combined with the low level of DNA homology ( $40 \%$ under optimum conditions) (10), are in our view sufficient to designate strains formerly named " $S$. durans" (Sherman and Wing) as a separate species, E. durans.

Enterococcus gallinarum. The following description of Enterococcus gallinarum (ex Bridge and Sneath 1982) comb. nov. (gall.in.ar'um. L.fem.gen. pl.n. gallinarum of hens) is based on previous descriptions $(2,3,10)$. Coccoid cells, mostly in pairs or short chains. Nonmotile. Colonies on blood agar or nutrient agar are circular, smooth, and entire. Beta-hemolytic on horse blood agar (2). Nonpigmented. Most strains do not survive heating at $60^{\circ} \mathrm{C}$ for $30 \mathrm{~min}$ (2) but survive heating at $60^{\circ} \mathrm{C}$ for $15 \mathrm{~min}(3)$. Grows slowly on thallous acetate-tetrazolium agar at room temperature, producing deep pink colonies (2). Ammonia produced from Larginine. Gelatin not liquefied. $\mathrm{H}_{2} \mathrm{~S}$ not produced. Other biochemical characteristics are given in Table 1 . Reacts with Lancefield group D antisera.

Group A peptidoglycan based upon lysine (type, Lys-DAsp). Low levels of menaquinones produced, with MK-8 predominating. The major non-hydroxylated long-chain fatty acids are hexadecanoic $\left(\mathrm{C}_{16: 0}\right)$ and octadecenoic $\left(\mathrm{C}_{18: 1}\right)$ acids; cis-11,12-methylenoctadecanoic acid $\left(\Delta \mathrm{C}_{19: 0}\right)$ is present in small amounts.

Isolated from intestines of domestic fowls. The guanineplus-cytosine content of the DNA ranges from 39 to 40 mol\%, as determined by melting temperature. The strains form a distinct homology group, as determined by DNADNA hybridization (10). The type strain is NCTC 11428 (= NCDO $2313=F 87 / 276$ ). This strain was isolated from a chicken intestine (2).

Description of the type strain. The characteristics of the type strain are the same as those described above for the species. Acid is not produced from glycogen.

Strains of $E$. gallinarum may be confused with those strains of $E$. faecalis and $E$. durans which are beta-hemolytic on horse blood agar. However, E. gallinarum differs from members of these species in a number of important respects (see above; Table 1).

Enterococcus malodoratus. The following description of Enterococcus malodoratus (ex Pette 1955) sp. nov. (mal. od.or.a'tus. M.L. n. malus ill; M.L.n. odoratus odor; malodoratus ill smelling) is based on previous descriptions (6, $10,13,19)$ and our observations. Coccoid cells, mostly in pairs or short chain. Nonmotile. Some strains produce slime. Colonies on blood agar or nutrient agar are circular, smooth, and entire. Usually does not grow at $45^{\circ} \mathrm{C}$. Usually does not survive heating at $60^{\circ} \mathrm{C}$ for $30 \mathrm{~min}$. Nonpigmented. Acetylmethylcarbinol not produced. $\mathrm{H}_{2} \mathrm{~S}$ produced. Other biochemical characteristics are given in Table 1 . Reacts with Lancefield group D antisera.

Group A peptidoglycan based upon lysine (type, Lys-DAsp). Respiratory quinones absent. The major non-hydroxylated long-chain fatty acids are tetradecanoic $\left(\mathrm{C}_{14: 0}\right)$ and hexadecanoic $\left(\mathrm{C}_{16: 0}\right)$ acids; octadecenoic acid $\left(\mathrm{C}_{18: 1}\right)$ and cis- 
11,12-methylenoctadecanoic $\left(\Delta \mathrm{C}_{19: 0}\right)$ acids are present in small amounts (less than $10 \%$ ).

Isolated from Gouda cheese. The guanine-plus-cytosine content of the DNA ranges from 40 to 41 mol\%, as determined by melting temperature. The strains form a distinct homology group, as determined by DNA-DNA hybridization. This species exhibits approximately 50\% homology with $E$. avium under optimum hybridization conditions; under stringent conditions the homology values with $E$. avium are less than $20 \%$ (10).

The type strain is strain NCDO 846 , which was isolated from Gouda cheese (19).

Description of the type strain. The type strain does not grow at $45^{\circ} \mathrm{C}$ or survive heating at $60^{\circ} \mathrm{C}$ for $30 \mathrm{~min}$. No acid is produced from glycerol, D-turanose, D-xylose, or L-xylose. Hippurate is not hydrolyzed (Table 1).

Strains of $E$. malodoratus are most likely to be confused with strains of $E$. avium since both produce $\mathrm{H}_{2} \mathrm{~S}$, do not hydrolyze arginine, and produce acid from a number of polyols; these properties are not shared with other enterococci. However, E. malodoratus strains may be distinguished from $E$. avium strains by a number of phenotypic characteristics (see above; Table 1).

\section{LITERATURE CITED}

1. Amstein, F., and P. A. Hartman. 1973. Differentiation of some enterococci by gas chromatography. J. Bacteriol. 113:38-41.

2. Barnes, E. M., G. C. Mead, C. S. Impey, and B. W. Adams: 1978. The effect of dietary bacitracin on the incidence of Streptococcus faecalis subspecies liquefaciens and related streptococci in the intestines of young chicks. Br. Poult. Sci. 19:713-723.

3. Bridge, P. D., and P. H. A. Sneath. 1982. Streptococcus gallinarum sp. nov. and Streptococcus oralis $\mathrm{sp}$. nov. Int. J. Syst. Bacteriol. 32:410-415.

4. Bridge, P. D., and P. H. A. Sneath. 1983. Numerical taxonomy of Streptococcus. J. Gen. Microbiol. 129:565-597.

5. Buchanan, R. E., and N. E. Gibbons (ed.). 1974. Bergey's manual of determinative bacteriology, 8th ed. The Williams \& Wilkins Co., Baltimore.

6. Collins, M. D., and D. Jones. 1979. The distribution of isoprenoid quinones in streptococci of serological groups D and N. J. Gen. Microbiol. 114:27-33.

7. Deibel, R. H. 1964. The group D streptococci. Bacteriol. Rev. 28:330-366.

8. Deibel, R. H., D. E. Lake, and C. F. Niven. 1963. Physiology of the enterococci as related to their taxonomy. J. Bacteriol. 86:1275-1282.
9. Deibel, R. H., and H. W. Seeley. 1974. Streptococcaceae p. 490-509. In R. E. Buchanan and N. E. Gibboris (ed.), Bergey's manual of determinative bacteriology, 8th ed. The Williams \& Wilkins Co., Baltimore.

10. Farrow, J. A. E., D. Jones, B. A. Phillips, and M. D. Collins. 1983. Taxoniomic studies on some group D streptococci. J. Gen. Microbiol. 129:1423-1432.

11. Guthof, O. 1955 . Uber eine neue serologische Gruppe $\alpha$ hamolytischer Streptokokken (serologische Gruppe Q). Zentralbl. Bakteriol. Parasitenkd. Infektionskr. Hyg. Abt. 1 Orig. 164:60-69.

12. Jones, D. 1978. Composition and differentiation of the genus Streptococcus, p. 1-49. In F. A. Skinner and L. B. Quesnel (ed.), Streptococci. Academic Press, Inc., London.

13. Jones, D., M. J. Sackin, and P. H. A. Sneath. 1972. A numerical taxonomic study of streptococci of serological group D. J. Gen. Microbiol. 72:439-450.

14. Kalina, A. P. 1970. The taxonomy and nomenclature of enterococci. Int. J. Syst. Bacteriol. 20:185-189.

15. Kilpper-Bälz, R., G. Fischer, and K. H. Schleifer. 1982. Nucleic acid hybridization of group $\mathrm{N}$ and group D streptococci. Curr. Microbiol. 7:245-250.

16. Langston, C. W., J. Guttierez, and C. Bouma. 1960. Motile enterococci (Streptococcus faecium var. mobilis N) isolated from grass silage. J. Bacteriol. 80:714-718.

17. Mundt, J. O., and W. F. Graham. 1968. Streptococcus faecium var. casseliflavus nov.var. J. Bacteriol. 95:2005-2009.

18. Nowlan, S. S., and R. H. Deibel. 1967. Group Q streptococci. I. Ecology, serology, physiology, and relationship to established enterococci. J. Bacteriol. 94:291-296.

19. Pette, J. W. 1955. De vorming van zwatelwaterstof in Goudse Kaas, veroorzaakt door melkzuurbacterien. Neth. Milk Dairy J. 10:291-302.

20. Schleifer, K. H., and O. Kandler. 1972. Peptidoglycan types of bacterial cell walls and their taxonomic implications. Bacteriol. Rev. 36:407-477.

21. Schleifer, K. H., and R. Kilpper-Bälz. Transfer of Streptococcus faecalis and Streptococcus faecium to the genus Enterococcus nom. rev. as Enterococcus faecalis comb.nov. and Enterococcus faecium comb.nov. Int. J. Syst. Bacteriol. 34:31-34.

22. Sherman, J. M. 1937. The streptococci. Bacteriol. Rev. 1:3-97.

23. Sherman, J. M., and H. U. Wing. 1937. Streptococcus durans n.sp. J. Dairy Sci. 20:165-167.

24. Skerman, V. B. D., V. McGowan, and P. H. A. Sneath (ed.). 1980. Approved lists of bacterial names. Int. J. Syst. Bacteriol. 30:225-420.

25. Thiercelin, E., and L. Jouhaud. 1903. Reproduction de l'enterocoque; taches centrales; granulations peripheriques et microblastes. C. R. Seances Soc. Biol. Paris 55:686-688.

26. Vaughn, D. H., W. S. Riggsby, and J. O. Mundt. 1979. Deoxyribonucleic acid relatedness of strains of yellow-pigmented group D streptococci. Int. J. Syst. Bacteriol. 29:204-212. 